\title{
Coral Reef and Shallow Water Benthic Identification Using Landsat 7 ETM+ Satellite Data in Nusa Penida District
}

\author{
Arief Reza Fahlevi a*, Takahiro Osawa b,c, I Wayan Arthana ${ }^{c}$ \\ a Graduate Study of Environmental Sciences, Udayana University, Denpasar, Bali 80232, Indonesia \\ ${ }^{b}$ Graduate School of Science and Engineering, Yamaguchi University, Ube Shi Tokiwadai 2-16-1, 7550092, Japan \\ c Center for Remote Sensing and Ocean Sciences (CReSOS), Udayana University, PB Sudirman Street, Denpasar, \\ Bali 80232, Indonesia \\ ${ }^{d}$ Faculty of Marine and Fisheries, Udayana University, Bukit Jimbaran, Bali 80361, Indonesia \\ *Correspondence: rezafahlevi_33@yahoo.co.id
}

Received: 9 September 2017; Accepted: 31 May 2018; Available online: 1 June 2018

\begin{abstract}
This study aims to investigate the feasibility of Landsat 7 ETM+ to identify coral reefs and shallow water benthic at Nusa Penida district in 2009 and 2012, comparison with the Reef Health Monitoring (RHM) results conducted by the Coral Triangle Center (CTC) using the Point Intercept Transect (PIT) method in the same periods. This study also aims to determine the changes of coral reefs and shallow water benthic cover during this period and the distribution at Nusa Penida districk. Shallow water benthic classification refers to English et al. (1997), with a modified by the addition of vegetation classes (seagrass and seaweed). The classification result using confusion matrix between the Reef Health Monitoring (RHM) with the classification of satellite image in 2009 obtained an accuracy rate of $65.85 \%$ with a kappa coefficient value of 0.525 , while in 2012 the accuracy value obtained of $74.81 \%$ with kappa coefficient value of 0.650 , which shows the results of that classification of satellite images of Landsat 7 ETM+ with the results of in-situ research is in a moderate level.
\end{abstract}

Keywords: coral reef; shallow water benthic; Nusa Penida district; Landsat 7 ETM+; water column correction

\section{Introduction}

Indonesia is a part of the "World's Coral Triangle". In addition to Indonesia, other countries belonging to this region is Malaysia, Papua New Guinea, Philippines, Solomon Islands, and Timor-Leste (Veron et al., 2009). This region also known has $30 \%$ of the world's coral reefs covers and more than $75 \%$ of the world's coral reef species and as habitat for more than 3,000 fish species (Allen and Werner, 2002; Hoegh-Guldberg et al., 2009).

Indonesia has about $51,000 \mathrm{~km}^{2}$ an area of coral reefs cover, with details of the $7 \%$ estimated in very good condition, $33 \%$ in good condition, $46 \%$ broken and $14 \%$ estimated in badly damaged condition (Burke et al., 2002). But until the end of 2016, according to research conducted by the Indonesian Institute of Sciences (LIPI) and Coral Reef Rehabilitation Management Program - Coral Triangle Initiative (COREMAP CTI) (Giyanto et al., 2017) in 1064 station from Aceh to Papua showed only $29.79 \%$ of Indonesia's coral reefs are in good condition, 35,06\% in the medium, and the rest are in poor condition severe $(35,15 \%)$. Nusa Penida District, Klungkung Regency, Bali Province-Indonesia, is one of the islands in Indonesia that managed coral reef and associated ecosystem with fairly structured. Nusa Penida district consist of three main island, that is Nusa Penida, Nusa Lembongan and Nusa Ceningan. Based on rapid survey by The Nature Concervancy 
reported Nusa Penida coastal and marine area has about 1,419 hectares coral reefs cover, 230,07 hectares mangrove cover and 108 hectares sea grass cover (Darma et al., 2011).

Sustainable and development research are needed in Nusa Penida islands to determine the current condition of the health of coral reef and associated ecosystem. In-situ data monitoring like Line Intercept Trancect (LIT), Manta Tow, Point Intercept Transect (PIT) and other similar methods are a favourite methods for researcher so far. But, this methods are need a long time and requires a considerable cost, and relatively only cover a small area in research.

An alternatives that can be done to minimize the impact is to utilize remote sensing technology. One of satellite image that is frequently used to map marine resources and fisheries are Landsat satellite images. In general, Landsat 7 ETM+ (Enhanced Thematic Mapper) has the same characteristics as it is predecessor (Landsat 4, 5 and 6) which carries the sensor TM (Thematic Mapper) to classify the wavelength radiance and separating into 7 band channel. Landsat 7 with additional sensors ETM (Enhanced Thematic Mapper) to classify the wavelength radiance into 8 band channels, with additional panchromatic band (band 8).

Test accuracy result between Landsat TM, SPOT XS, merged of Landsat TM with SPOT Pan, and Landsat MSS in mapping shallow waters benthic at Caicos Bank for 4 types of habitat (sand, corals, macroalgae and seagrass) with water column correction and contextual editing for all case, Landsat TM has overall accuracy of $73 \%$, while SPOT XS has overall accuracy of $67 \%$, merged of Landsat TM with SPOT Pan has accuracy not significant differ with SPOT XS, and the Landsat MSS has overall accuracy $<60 \%$ (Shepperd et al., 1995, in UNESCO, 2013).

Reffers to Landsat TM accuracy result to mapping shallow water benthic at Caicos Bank on 1995, and with asssumption the Landsat TM and Landsat 7 ETM+ satellite image has the same spectral range and spatial resolution on each bands (except band 8 that are not available on Landsat TM), it is possible to investigates the feasibility of Landsat $7 \mathrm{ETM}+$ to identified the coral reefs and shallow water benthic, and in this research will be compare with in-situ data conducted Reef Health Monitoring (RHM) result using Point Intercept Transect (PIT) methods by Coral Triangle Centre at Nusa Penida District, Klungkung Regency, Bali Province - Indonesia on 2009 and 2012. Landsat Data can be downloaded for free through the site http://earthexplorer.usgs.gov/.

\section{Materials and Methods}

\subsection{Study Site}

Study site is Nusa Penida district, Klungkung Regency, Bali Province - Indonesia. The figure 1 represented maps of Nusa Penida district, a white colour represented a unclassified area (lands and depth sea) and a mix colour represented a classified area (shallow waters area).

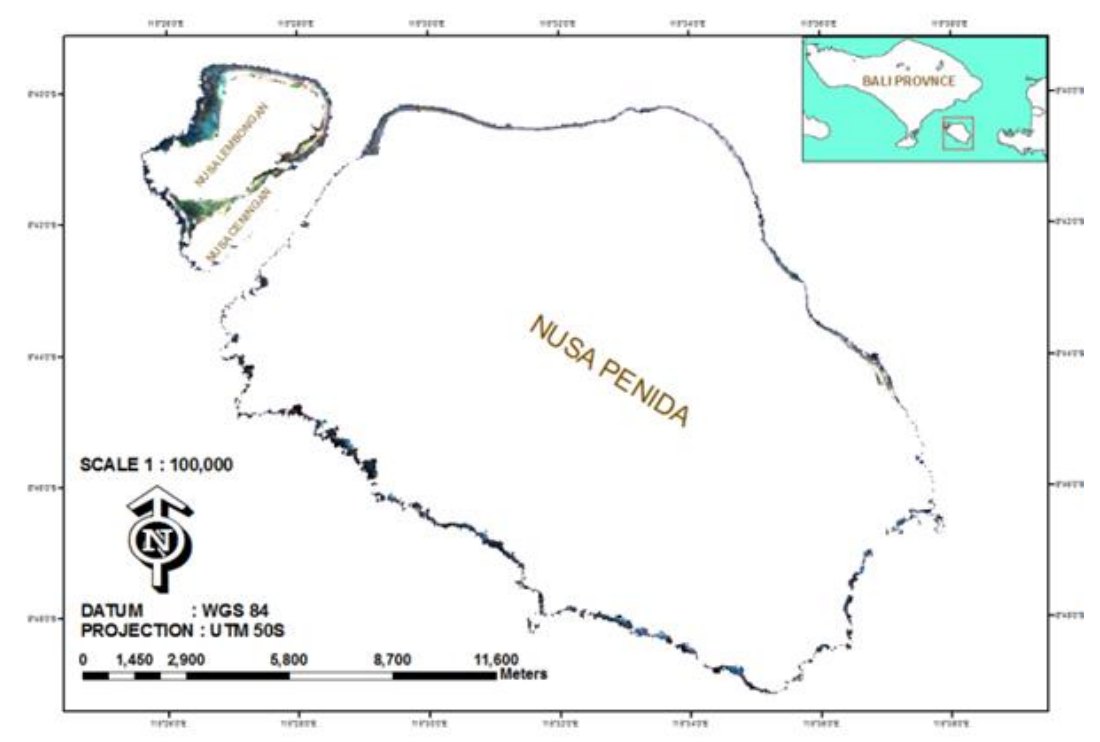

Figure 1. Study area map 


\subsection{Used Data}

\subsubsection{In-situ Data}

In-situ data obtained from Reef Health Monitoring (RHM) survey conducted by Coral Triangle Centre (CTC) on 28 October - 2 November 2009 (14 stations) and on $19-23$ September 2012 (12 stations), as shown Figure 2 and Figure 3.

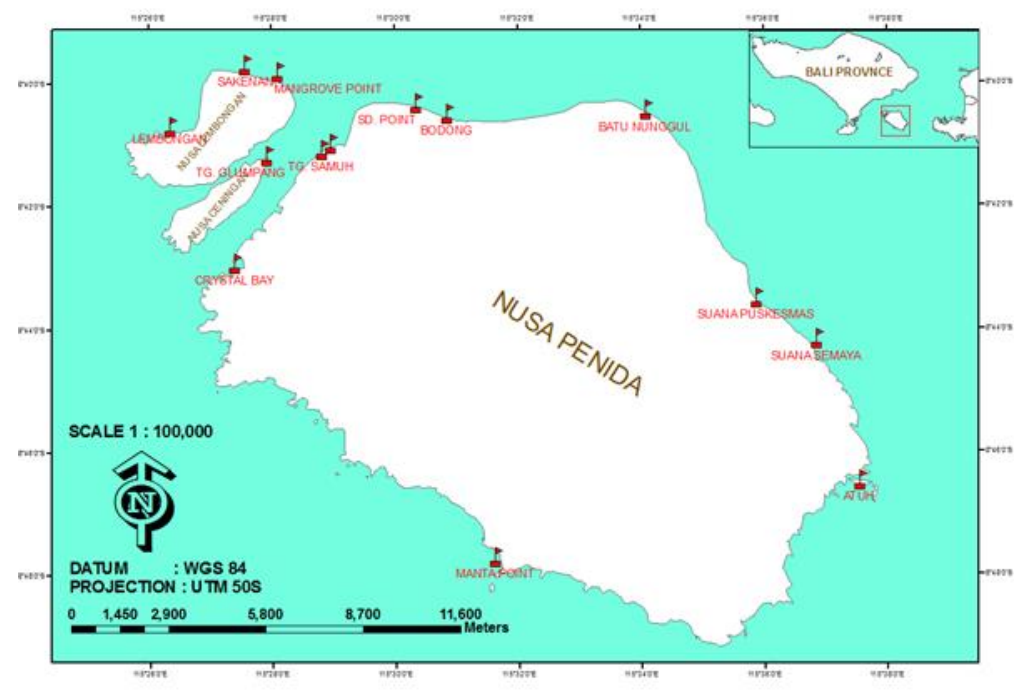

Figure 2. Nusa Penida RHM station on 2009

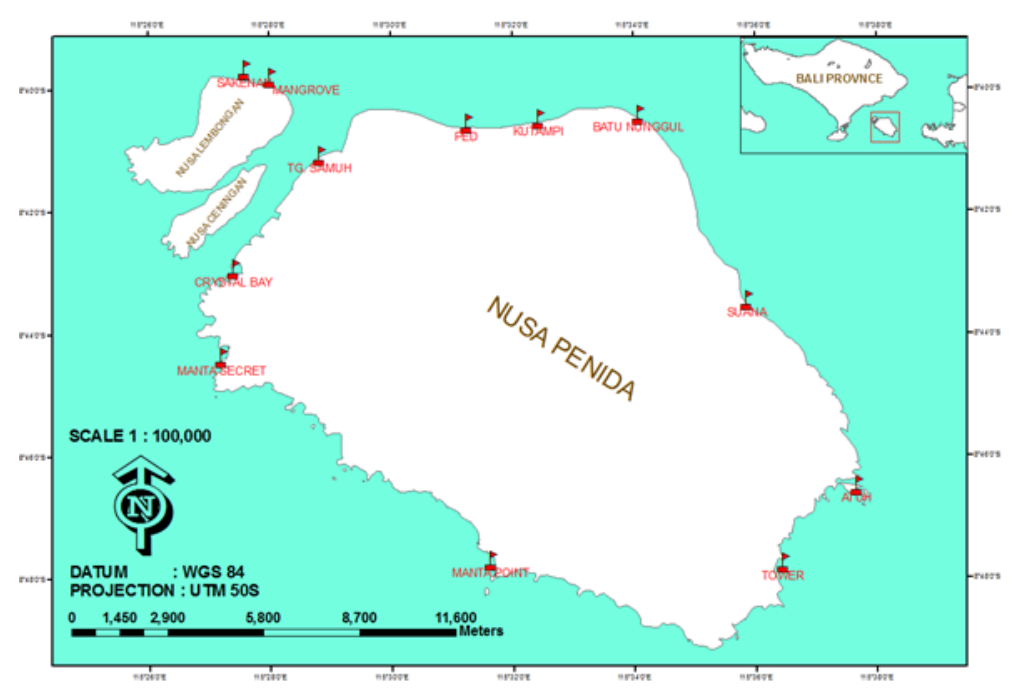

Figure 3. Nusa Penida RHM station on 2012

Refers to Kirkman et al., (1998), is quite difficult to differentiate between algae with seagrass with remote sensing technology because photosynthetic pigments that are in both classes are similar, so that the spectral radiance received by satellite sensors have a similar range. In addition, algae also live in symbiosis with the coral (zooxanthallae is a photosynthetic pigment in algae found in the reef). Zooxanthallae pigment also found in others class (especially at soft coral from xeniidae and clavularia sp). In this research, the limited of vegetation class (seaweed and seagrass) data will cause the results of supervised classification in the shallow waters will be biased and will be classified into the reef class, others class or algae class (refers to classification of basic compiler components reef ecosystem based coral life form by English et al. (1997).

Reef Health Monitoring (RHM) generally do not cover vegetation class data. Additional vegetation data is needed because shallow water around Nusa Lembongan and Ceningan 
dominated by seaweed, seagrass, sands and rubble. Figure 4 represented addition data of seaweed and seagrass location obtained from ground truth monitoring at 7 locations in Nusa Lembongan shallow water on 2014.

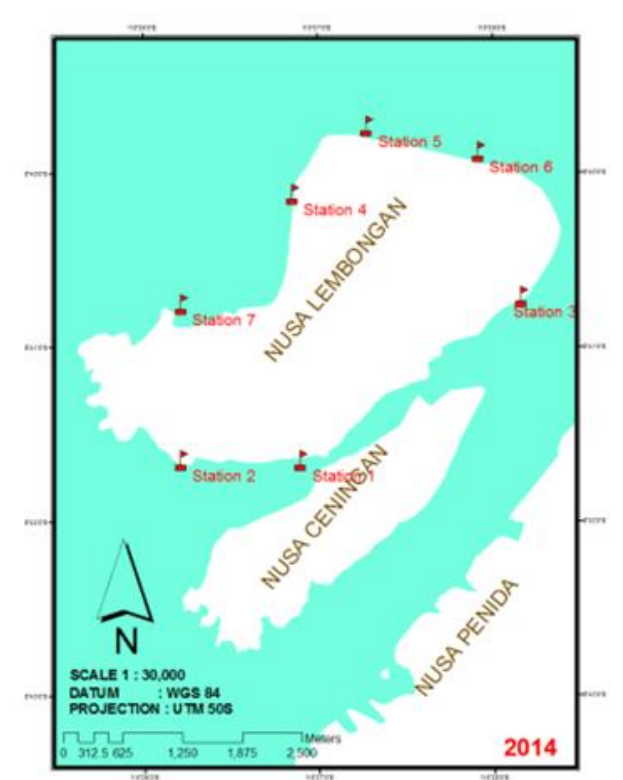

Figure 4. Nusa Lembongan vegetation ground truth location on 2014

\subsubsection{Satellite Data}

Landsat 7 ETM+ launched on 15 April 1999 to bring ETM+ Scanner, have an orbit aligned with the sun (sun synchronous), crossing the equator at 10:00 local time, and covered the same area (repeat covearge interval) every 16 days with a swath width of each coverage is $185 \mathrm{~km}$, more details about the characteristics of Landsat 7 ETM+ can be seen in Table 1.

Table 1. Landsat $7 \mathrm{ETM}+$ characteristic

\begin{tabular}{ll}
\hline System & Landsat 7 ETM+ \\
\hline Swath width: & 185 kilometers \\
Repeat coverage interval: & 16 days (233 orbits) \\
Altitude: & 705 kilometers \\
Quantization: & Best 8 of 9 bits \\
On-board data storage: & -375 Gb (solid state) \\
Inclination : & Sun-synchronous, 98.2 degrees \\
Equatorial crossing: & Descending node;IO:OOam +/- IS min. \\
Launch vehicle: & Delta II \\
Launch date: & Apr-99 \\
\hline \multicolumn{2}{c}{ Source: http://geo.arc.nasa.gov/sge/landsat/17.html }
\end{tabular}

Landsat 7 ETM+ are composed of seven different bands plus one panchromatic bands, with a different ground resolution range as seen on the Table 2. Each bands representing a different portion of the spectral. Shorter range of wave length, better the ability to differentiated obyek on the earth. Base on Lillesand et al. (2004) statement, that the best light penetration in pure water are in the band channel that has a range of wavelengths from $0.48-0.6 \mu \mathrm{m}$. In the Landsat $7 \mathrm{ETM}+$ satellite image, the wavelength range between $0.48-0.6 \mu \mathrm{m}$ contained in the band 1 (blue) and band 2 (green). 
Table 2. Band of Landsat 7 ETM+ (Chander et la., 2009)

\begin{tabular}{ccc}
\hline Band Number & Spectral Range $(\mu)$ & Ground Resolution $(\mathrm{m})$ \\
\hline 1 & 0.45 to 0.515 & 30 \\
2 & 0.525 to 0.605 & 30 \\
3 & 0.63 to 0.690 & 30 \\
4 & 0.75 to 0.90 & 30 \\
5 & 1.55 to 1.75 & 30 \\
6 & 10.40 to 12.5 & 60 \\
7 & 2.09 to 2.35 & 30 \\
Pan & 0.52 to 0.90 & 15 \\
\hline
\end{tabular}

Source: http://geo.arc.nasa.gov/sge/landsat/17.html

\subsection{Metodology}

\subsubsection{Gapfill Image}

On 31 May 2003, the Scan Line Corrector (SLC) on Landsat 7 ETM+ has a damage. This is known as the SLC-off. SLC is a technology on Landsat 7 ETM+ is designed to fill the gaps in satellite images of Landsat $7 \mathrm{ETM}+$, which is caused by the forward motion of the satellite during orbit. As a result of this damage, estimated at about $22 \%$ of the image produced on a path/row losing information (Scaramuzza and Barsi, 2005).

One technique to fill the gaps information occurs, using alghoritm named Localized Linear Histogram Match (LLHM) as shown at Figure 5. Pixels on the image which gapfill filled by another image that does not lose information, while minimizing the area that experienced gapfill image pixels in the same area both the primary image and the fill image. This methods using moving windows.

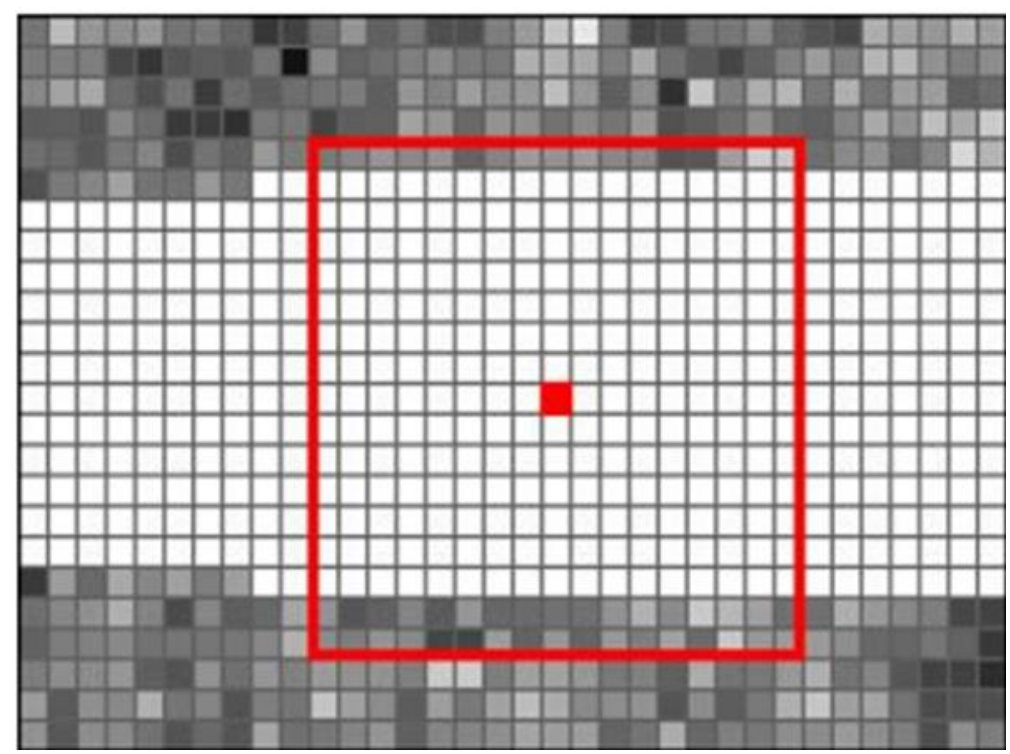

Figure 5. Moving Window ilustrated for LLHM (Scaramuzza et al., 2004)

Alghoritm results obtained in use to calculate the value of the missing pixels in the primary image pixel base of the fill image pixel. The equation for LLHM are (Scramuzza et al., 2004):

$$
\text { MergedDN }=\text { Fill }_{D N} \times \text { Gain }+ \text { Bias }
$$




$$
\begin{gathered}
\text { Gain }=\frac{\sigma_{p}}{\sigma_{F}} \\
\text { Bias }=\mu_{P}-\mu_{F} \times \text { Gain }
\end{gathered}
$$

Where:

$$
\begin{gathered}
\mu_{P}=\frac{1}{N} \sum_{n=1}^{N}{\text { Pr } \text { imary }_{D N}}_{\sigma_{P=} \frac{1}{N-1} \sum_{n=1}^{N}\left(\text { Primary }_{D N}-\mu_{P}\right)^{2}} \\
\mu_{F}=\frac{1}{N} \sum_{n=1}^{N} \text { Fill }_{D N} \\
\sigma_{F}=\frac{1}{N-1} \sum_{n=1}^{N}\left(\text { Primary }_{D N}-\mu_{F}\right)^{2}
\end{gathered}
$$

With the principle of Linear Localized Histogram Match (LLHM), then developed software named Frame and Fill. To consider in choosing a filler image are (i) the position of the gap between the primary image and the fill image does not the same coordinates, (ii) the date of the recording between the primary image and the fill image is not too much effort, (iii) the fill image selected should have a low cloud cover or none at all (USGS, 2004).

\subsubsection{Athmospheric Correction}

Assuming that the entire visible band radiance will be absorbed entirely in the deep ocean will be absorbed, so that the radiance values recorded by the sensor radiance value is simply due to the influence of the atmosphere (Green et al., 2000). Armstrong (1993) suggested, the value of the average radiance deep ocean should be reduced by 2 multiply the standard deviation. This methods is known as the Dark Pixel Substraction, can be written by the following equation:

$$
\text { Athmospheric Correction }=L i-L s i
$$

Where $L_{i}$ is pixel radiance in band $i$ and $L_{s i}$ is the average pixel radiance in depth water.

\subsubsection{Classification of Water Body}

The states of Beer-Lambert law, the light of intensity decreases exponentially to the difference depth (Bukata et al., 1995). Then by to transform the light of intensity using the natural logarithm (ln) will make the relationship with the depth becomes linear. The equation can show below:

$$
X_{i}=\operatorname{Ln}\left(L_{i}\right)
$$

Lyzenga (1981) developed techniq to remove the influence of the depth using attenuation coefficient between band $i$ and band $j$. The value attenuation coefficient did not obtained from linear regression, but obtained from calculated the smallest deviation of the linear correlation line:

$$
\frac{K i}{K j}=a+\sqrt{a^{2}+1}
$$

Where: 


$$
a=\frac{\operatorname{variance}_{b i}-\text { var iance }_{b j}}{2 \times \operatorname{cov} \text { ariance }_{\text {bandij }}}
$$

Depth Invariant Index (water colum correction) alghoritm then calculated using alghoritm 12 below:

$$
Y=\text { In Band }_{i}-\left(\frac{k i}{k j}\right) \times \operatorname{In} \text { Band }_{j}
$$

\subsubsection{Image Classification}

Supervised classification with maximum likelihood method will be used to generate the different classes for each habitat, which was trained using field data. Shallow water benthic classification refers to English et al. (1997), and modified with additional vegetation class (seagrass and seaweed).

\subsubsection{Accuracy Test}

Accuracy test is done by comparing the two map, ones derived from the analysis of remote sensing (data to be tested) and the other is a map derived from other sources (Campbell and Wynne, 2011). Standard format for reporting test results accuracy is in the form of an error matrix, or also called "confussion matrix".

\section{Results}

\subsection{Preprocessing}

\subsubsection{In-situ Data}

Shallow water benthic coverage on Nusa Penida district on 2009 and 2012 by Reef Health Monitoring (RHM) conducted by Coral Triangle Centre Survey on 2009 and 2012 using Point Intercept Transect (PIT) methods can be seen on figure 6 and 7.

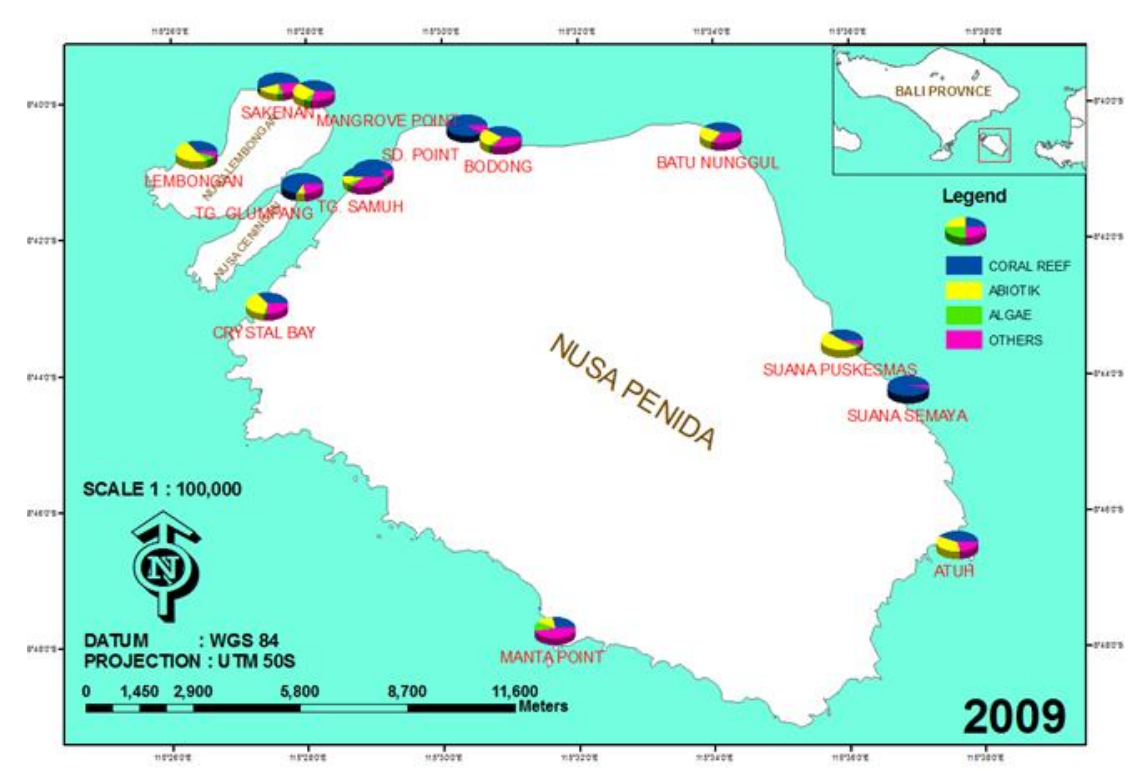

Figure 6. Shallow water benthic coverage at Nusa Penida District in 2009 


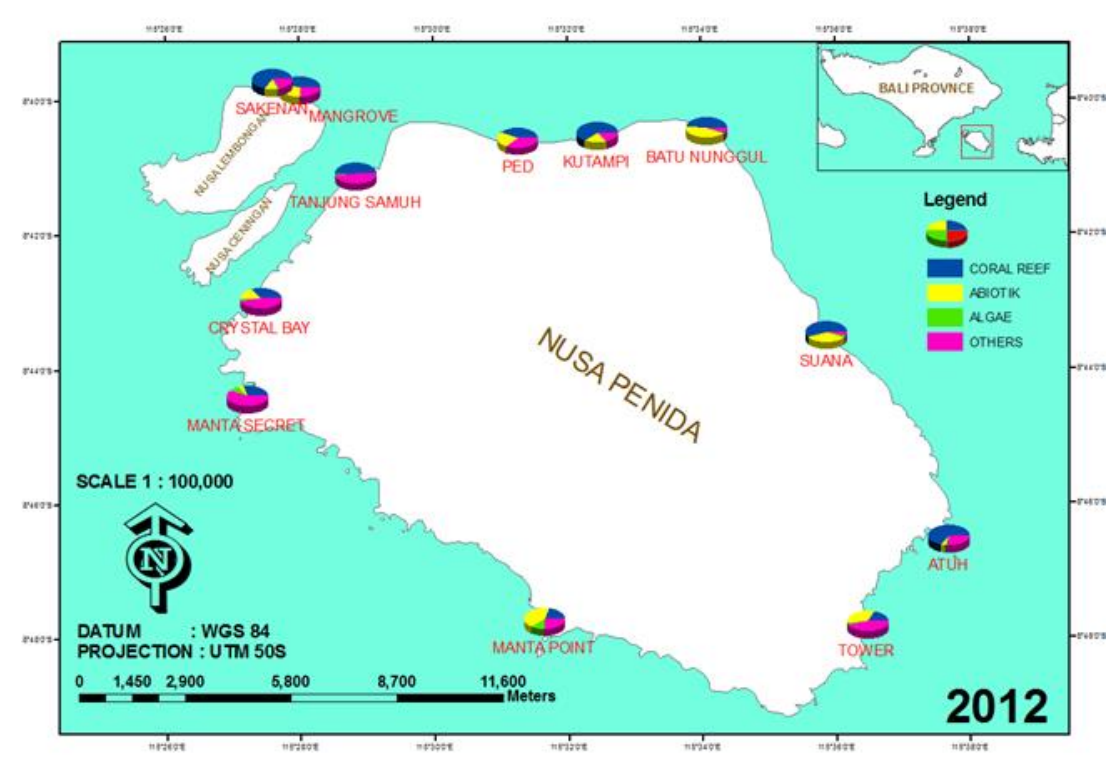

Figure 7. Shallow water benthic coverage at Nusa Penida District in 2012

Figure 8 represented ground truth monitoring location of vegetation class. Vegetation class sample is important, because, zooxanthellae photosynthetic pigments that live in symbiosis with the coral reefs, have a similar spectral characteristics of the photosynthetic pigments in seagrass or seaweed.

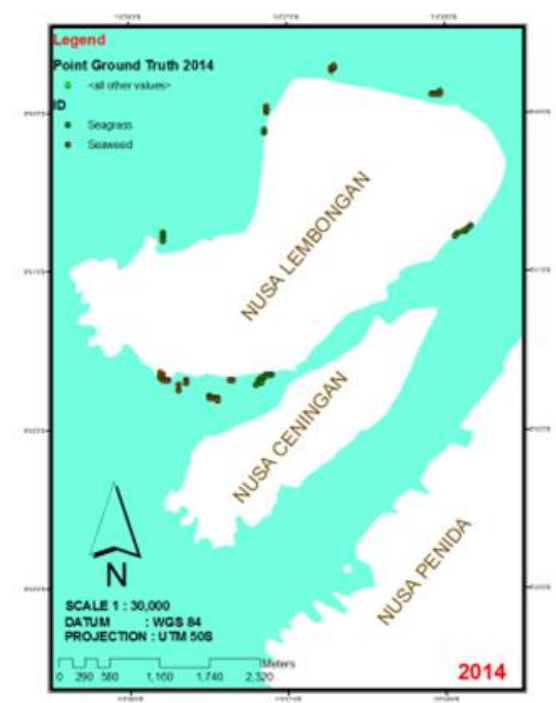

Figure 8. Seagrass and seaweed cultivation location on 2014 (base on ground truth survey)

\subsubsection{Gapfill Image}

Satellite data using Landsat 7 ETM+ level $1 \mathrm{~T}$ at path/row 116/066 acquisition 15 October 2009 as primary image and 21 march 2009 as fill image. In 2012, satellite image used is Landsat 7 ETM+ acquitition 26 february 2012 as primary image and 23 october 2012 as a fill image. Figure 9 and 10 show the gapfill Landsat 7 ETM+ processing on 2009 and 2012 satellite image: 

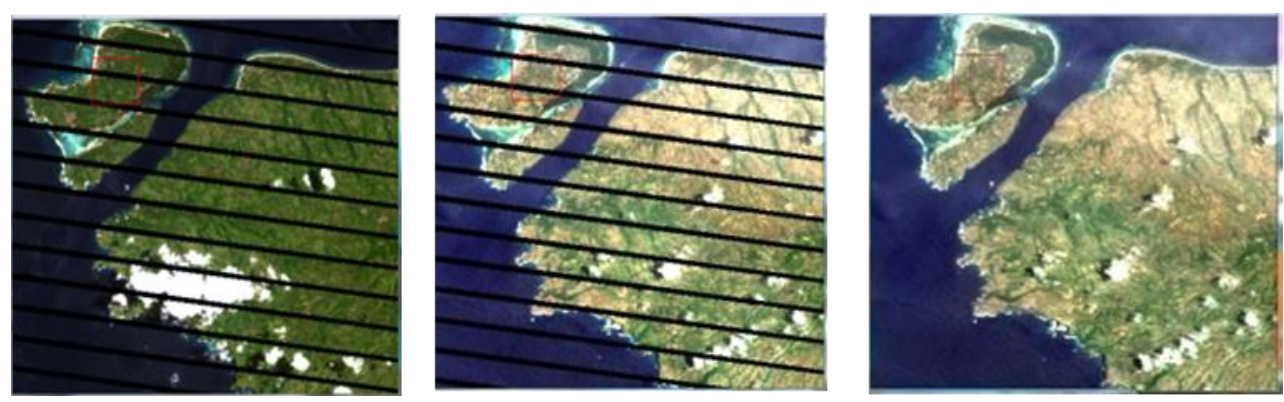

Figure 9. Gapfill processing on 2009 satellite image
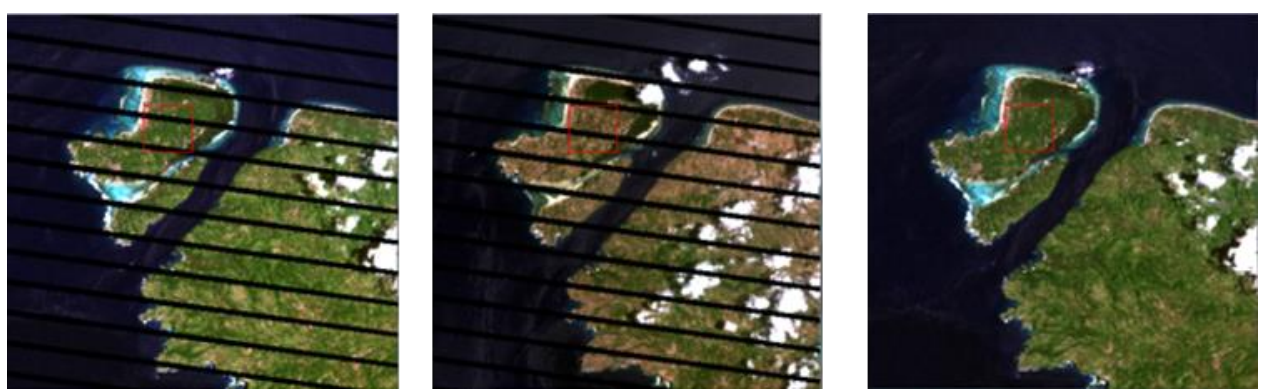

Figure 10. Gapfill process on 2012 satellite image

\subsubsection{Athmospheric Correction}

Athmospheric correction have be done with Dark Pixel Substraction methods.

\subsubsection{Croping Image}

Crooping image intended to limited the Area of Interest (AOI) between 2009 and 2012 and make Area of interest of both image have the same extents. Table 3 represented about upper and lower coordinates using for crooping image:

Table 3. Crooping Image coordinates

\begin{tabular}{ccc}
\hline UTM (meter) & Easting & Northing \\
\hline Upper Right & 325035 & 352065 \\
Lower Right & 9044065 & 9023395 \\
Zone & 50 South of Equator \\
\hline
\end{tabular}

\subsubsection{Image Masking}

Image Masking mentioned to separate the areas out of the study area. In this research, first step, image masking is intended to separated between land and sea with near Infrared Band (Band 4) on Landsat 7 ETM+ imagery which has a spectral between 0.760.90 is used as a masking. Second step do to masking depth water and shallow water area using shape file, obtained from the digitized of Landsat 7 ETM+ satellite images on the boundary between the depth water and shallow waters. Figure 11 represented image masking processing on 2009 and 2012 on Landsat 7 ETM+ satellite image. Black colour represented unclassified area (land and depth water) mix colour represented classified area (shallow water). 

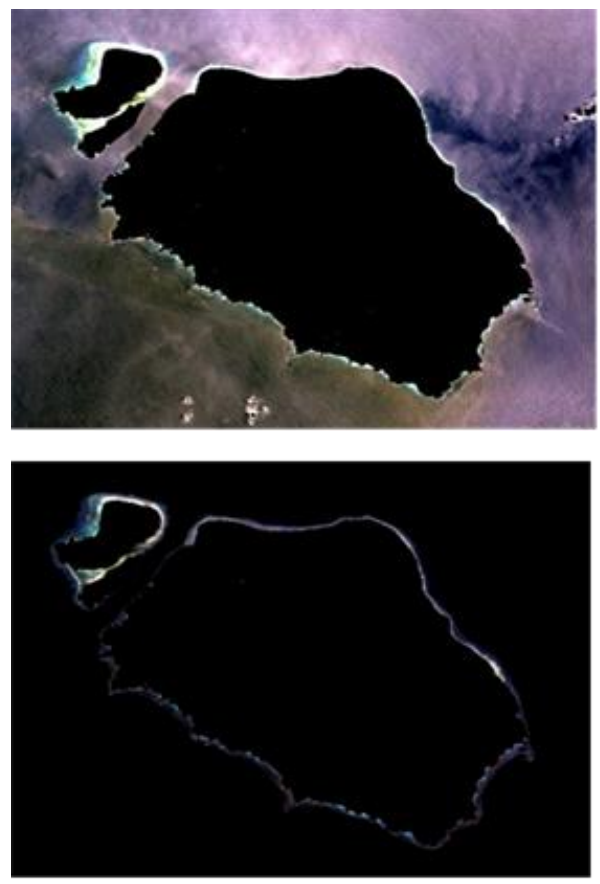

2009
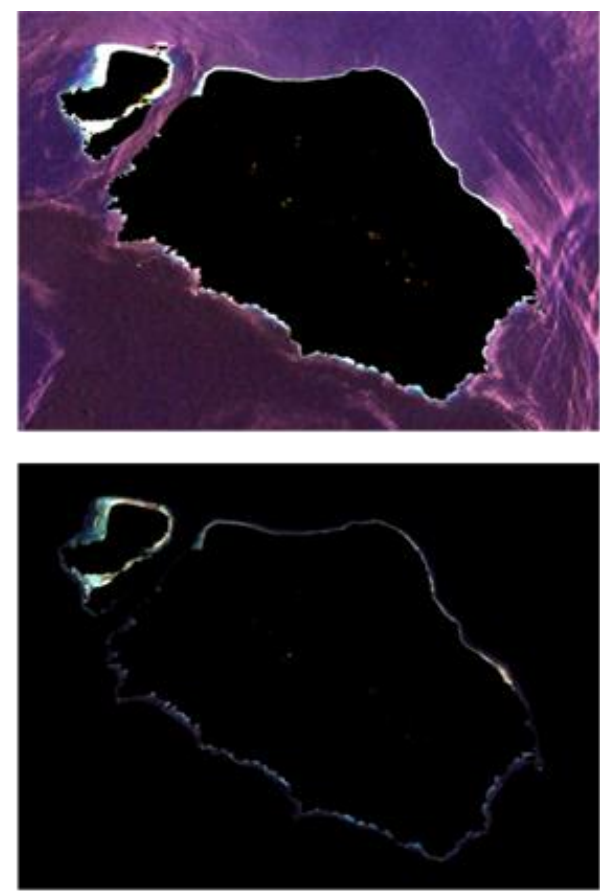

2012

Figure 11. image Masking process

\subsection{Classification of Water Body}

The light of intensity decreases exponentially to the difference depth (Beer-Lambert Law). The good linear correlation between the two band channels when sampling substrate obtained on the same substrate at different depths (Lyzenga, 1981). Figure 12 and 13 using the distribution of coral reefs as trained area sample. With transform the radiance using natural loghartim, the relationship between depth and radiance getting a linear correlation.
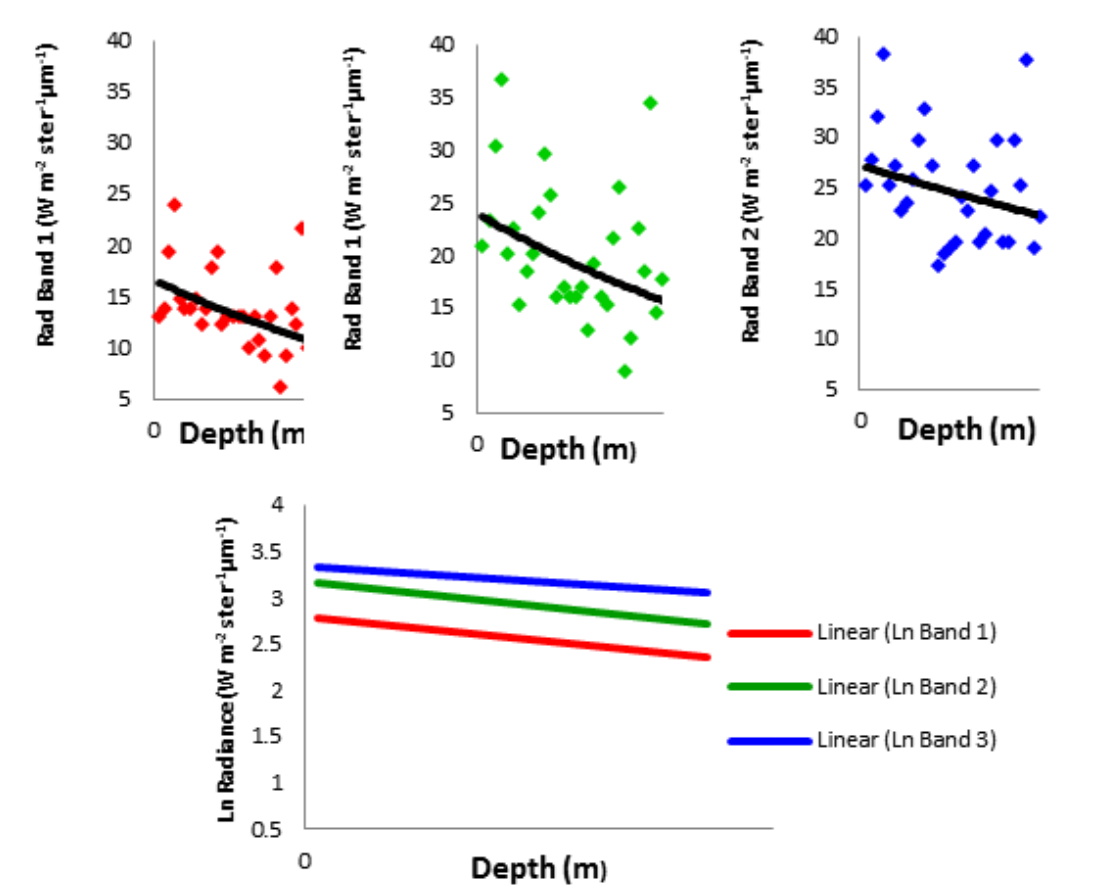

Figure 12. Linearis relationship between radiance with the depth on coral reef substrat at 2009 

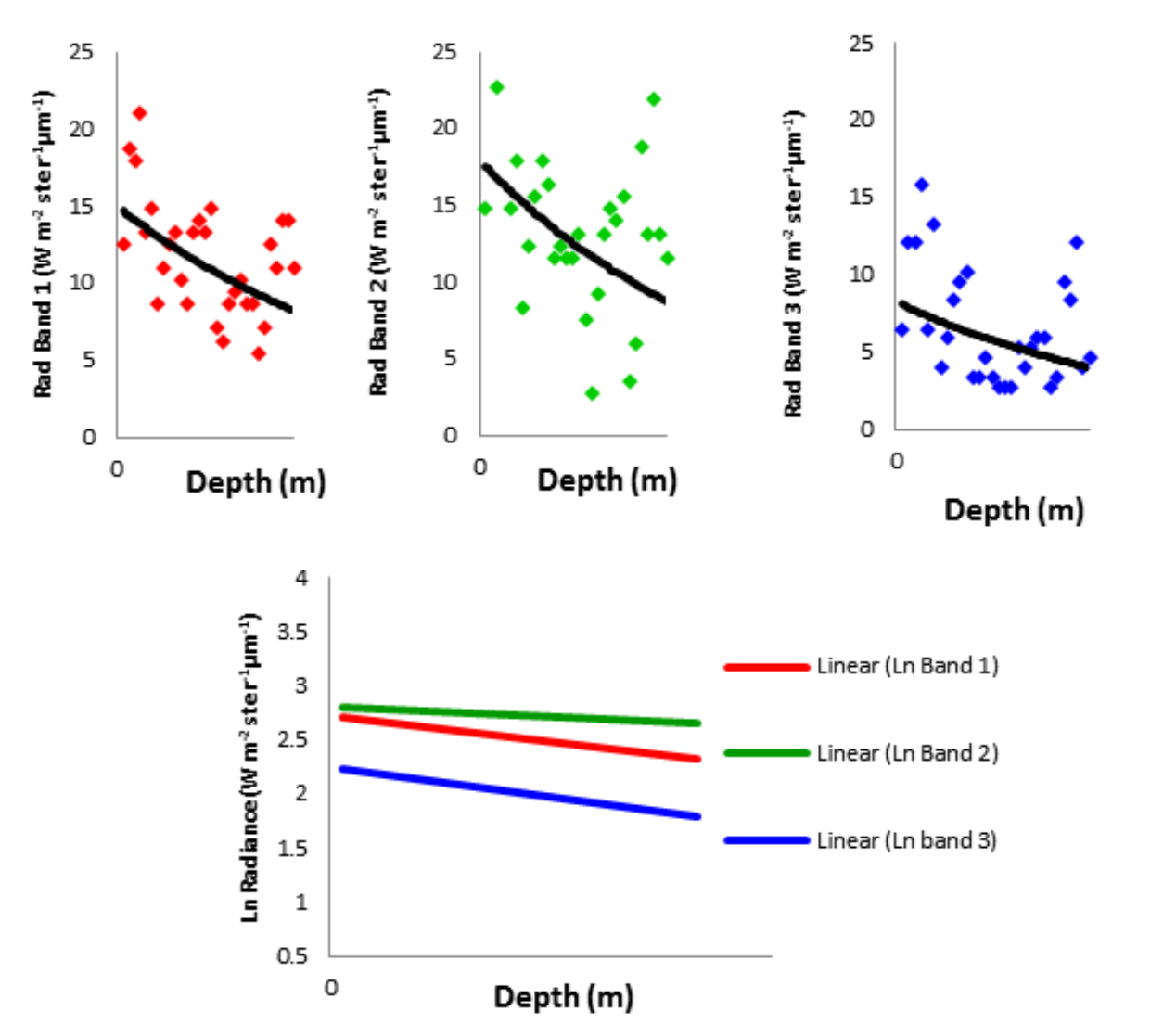

Figure 13. Linearis relationship between radiance with the depth on coral reef substrat at 2012

Figure 14 presented of linearise between differences depth and the spectral radiance in the water body on Landsat 7 ETM+ satellite image on 2009 and 2012. The difference colour represented about the difference depth, because spectral radiance from bottom water getting linear with the depth.
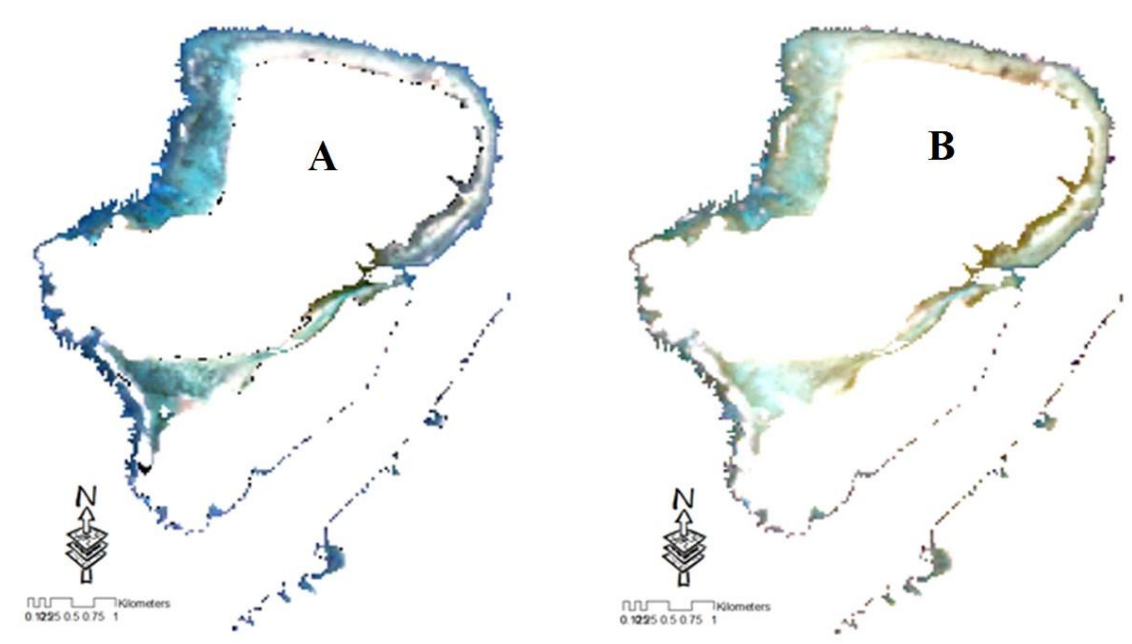

Figure 14. Transform radiance result A. 2009 B. 2012

The cofficient $(\mathrm{k})$ band $\mathrm{i}$ obtanined from a linear regression are the attenuation coeficient of band $\mathrm{i}(\mathrm{ki})$ to the differences depth. Using linear regression to correlate between the two bands, the difference wavelength in each different bands can minimize or even removed, the cooeficient correlation values between band $i(k i)$ with band $j(k j)$ 
known as attenuation coefficient ( $k i / k j$ ) between two band, as represents at Figure 15 and 16.

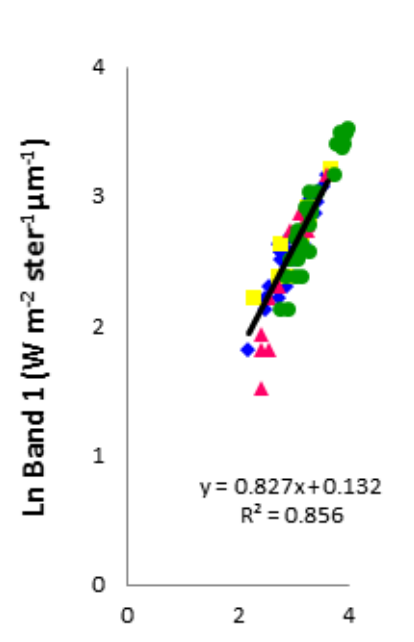

Ln Band 2 $\left(\mathrm{W} \mathrm{m}^{-2}\right.$ ster $\left.^{-1} \mu \mathrm{m}^{-1}\right)$

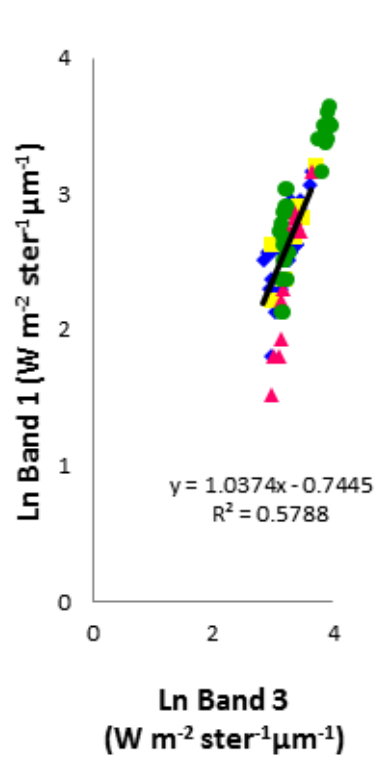

Figure 15. Transform band i against band $j$ at various depth in 2009 (coral reef benthic)
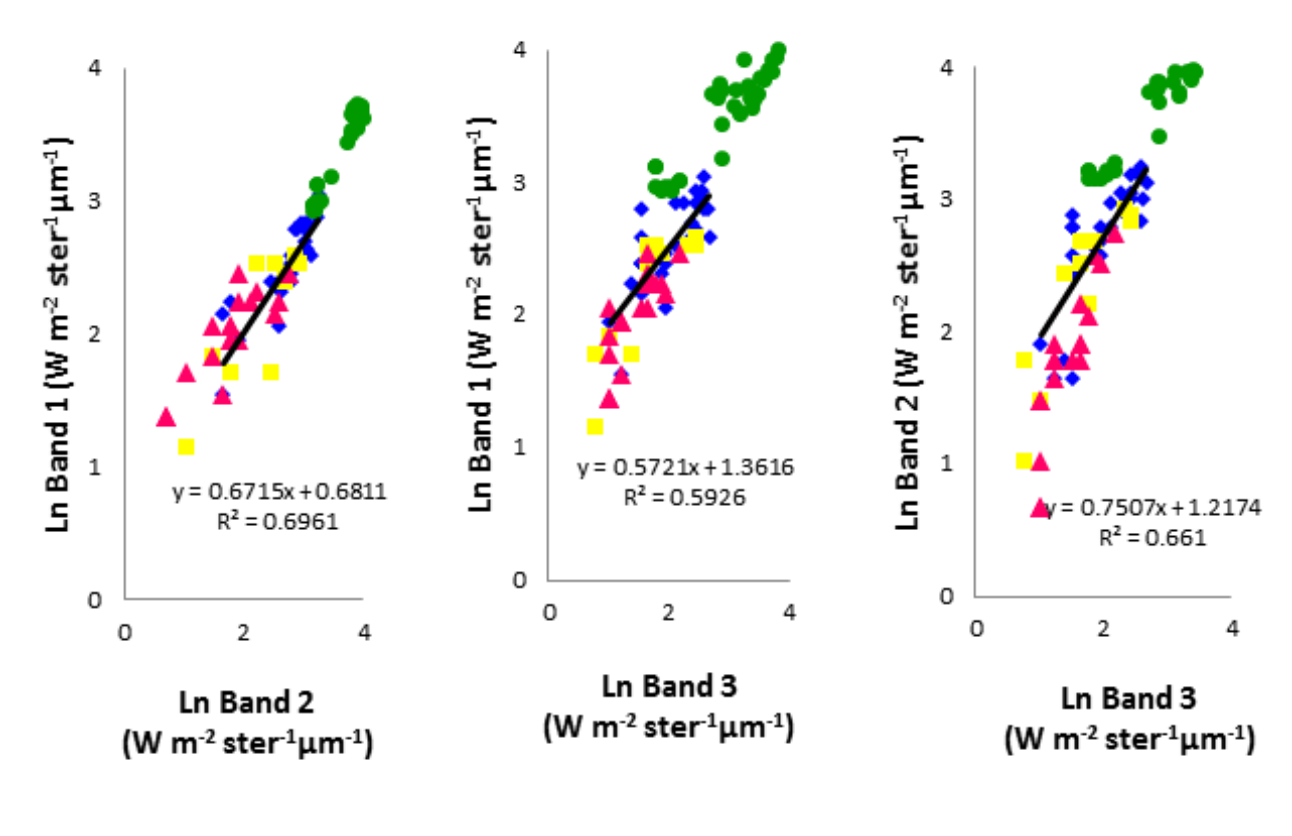

Figure 16. Transform band $\mathrm{i}$ against band $\mathrm{j}$ at various depth in 2012 (coral reef benthic)

The correlation between natural logharitm (ln) band $\mathrm{i}$ and band $\mathrm{j}$ using linear regression is the basic of alghoritm depth invariant index (water column correction). With the R-square value $\left(R^{2}\right)$ in 2009 amounted to $0.856,0.578,0.757$, and in 2012 amout to $0.696,0.592,0.661$ indicate a "strong" and "very strong" level correlation between the natural logharitm (ln) band 1 , band 2 and band 3 .

The result of calculation attenuation coefficient ( $k i / k j)$ using the conventional linear regression analysis will produce coeffisient value with dependent variable, so the equation obtained using regression linear ignored. Attenuation cooeficient (ki/kj) between band i and band $\mathrm{j}$ will calculated from variance and covariance training data at difference depth. Base on equation 11, the calculation attenuation coefficient between natural logharitm (ln) band $\mathrm{i}$ and band $\mathrm{j}$ can see on the Table 4. 
Table 4. Calculation of attenuation coeffisient values

\begin{tabular}{ccc}
\hline $\mathrm{ki} / \mathrm{kj}$ & 2009 & 2012 \\
\hline $\ln \mathrm{b} 1 \mathrm{~b} 2$ & 0.882347 & 0.764596 \\
$\ln \mathrm{b} 1 \mathrm{~b} 3$ & 1.515810 & 0.673733 \\
$\ln \mathrm{b} 2 \mathrm{~b} 3$ & 1.642124 & 0.903495 \\
\hline
\end{tabular}

Figure 17 presented the affect of the depth have been minimized using depth invariant index alghoritm (equation 12) at 3 visible band in Landsat 7 ETM+ using band math in ENVI 4.8. Attenuation coefficient $(k i / k j)$ values obtained from the coefficient at Table 4. The different color on the satellite image shown a different spectral radiance (reflectance) from a different dominant benthic at the bottoms.
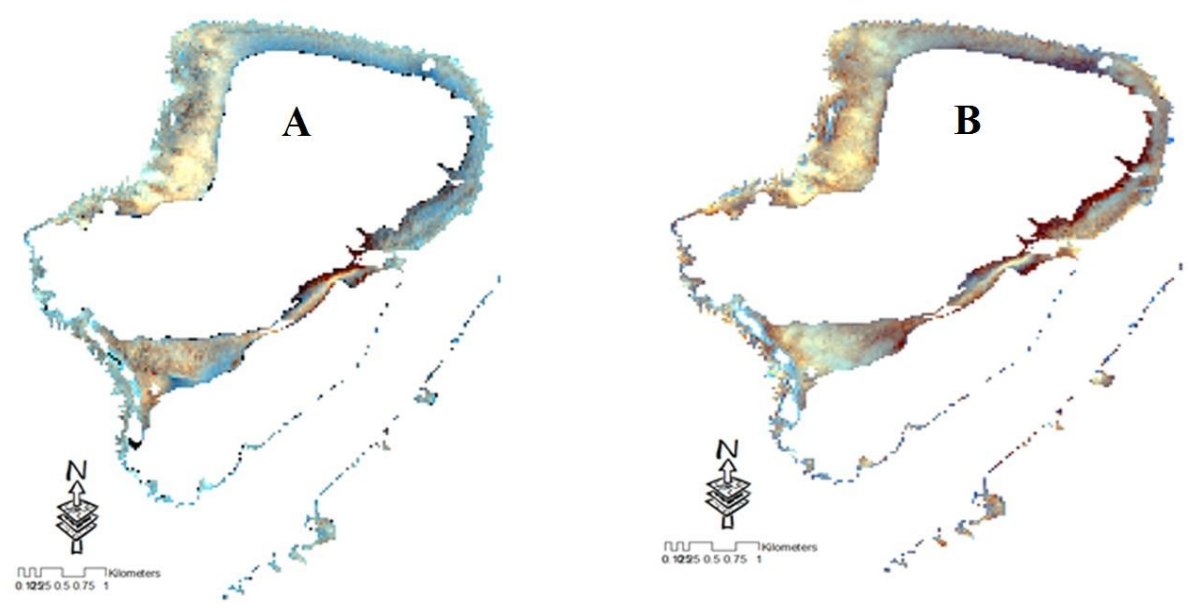

Figure 17. Water Column Correction result A.2009; B. 2010

\subsection{Image Classification}

Image classification is intended to provide a different color pixels for each thematic class based on their spectral properties as shown at Figure 18. Supervised classification with maximum likelihood method will be used to generate the different classes for each habitat, which was trained area using Reef Health Monitoring data.

Table 5 represented change detection on the shallow water benthic covered at Nusa Penida coastal from 2009 to 2012. Study area covers after image resize was about $560,142,000 \mathrm{~m}^{2}$, then divided into two regions, 1) unclassified region (presented to land and depth sea) with an area of $538,725,600 \mathrm{~m}^{2}(96.18 \%)$, and 2) classified region (presented coastal region) with an area of $21,416,400 \mathrm{~m}^{2}(3.82 \%)$.

With a study area of approximately $21,416,400 \mathrm{~m}^{2}$ (ignored unclassified area), live coral reefs cover area of $28.59 \%$ in 2009 and decreased to $23.34 \%$ in 2012 . Reffering to Gomez and Yap (1998), the condition of live coral cover at Nusa Penida decreased from moderate (2009) to damage (2012).

\subsection{Accuracy Test}

The classification results of the Landsat 7 ETM + satellite images will be compared with data obtained from field surveys result in 2009 and 2012. The method used is known by the confussion matrix. Accuracy test result using confussion matrix method can be seen in the Table 6. 


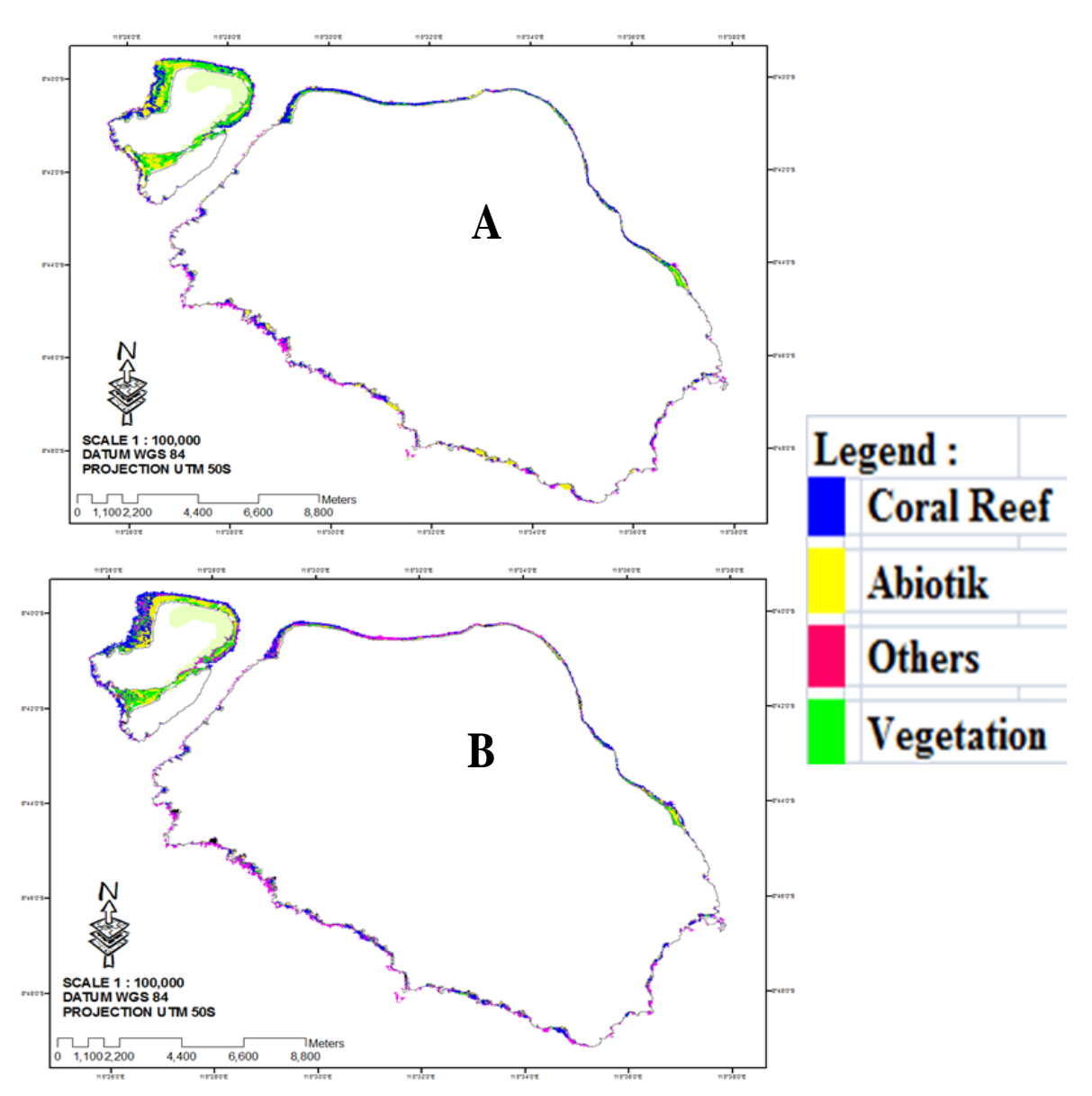

Figure 18. Shallow water benthic classification on result A. 2009 B. 2012

Table 5. Nusa Penida shallow water benthic change detection 2009-2012

\begin{tabular}{crrrrr}
\hline \multirow{2}{*}{ Year } & \multicolumn{5}{c}{ Coverage Area $(\mathrm{m} 2)$} \\
& Unclassified & \multicolumn{2}{c}{ Classified } \\
& & \multicolumn{1}{c}{ Coral Reef } & \multicolumn{1}{c}{ Abiotik } & \multicolumn{1}{c}{ Others } & Vegetation \\
\hline 2009 & $538,725,600$ & $6,121,800$ & $2,329,200$ & $10,512,000$ & $2,453,400$ \\
2012 & $538,587,000$ & $4,997,700$ & $4,862,700$ & $8,694,900$ & $2,999,700$ \\
Change Detection & $(138,600)$ & $(1,124,100)$ & $2,533,500$ & $(1,817,100)$ & 546,300 \\
Percentage Change & -0.0257 & -18.3622 & 108.7713 & -17.2860 & 22.2671 \\
\hline
\end{tabular}

Figure 19 presented the accuracy test by based on Table 6. Classification results show the ability of Landsat 7 ETM+ satellite images to distinguishing types of shallow water benthic covered at different depths by comparing the results of a user classification (insitu data) with the results of the producer classification (satellite image) using statistics calculation in Ms. Excell 2007. Vegetation class has the highest degree of accuracy both producer accuracy (satellite images) and user accuracy (in-situ data). Abiotic class have a intermediate level of accuracy which producers classification generated lower than the insitu data results.. Class coral reefs have a intermediate level of accuracy, both producer accuracy (satellite images) and user accuracy (in-situ data). Error in this class tend to be balanced between the satellite image with of in-situ data. Class others have a accuracy level that is nearly identical to the coral reefs classes, but the satellite image classification result is higher than in-situ data classification, especially in 2009. Base on Maingi et al. (2002), kappa coefficient on 2009 and 2012 is moderate level. 
Table 6. Accuracy test using confussion matrix methods

\begin{tabular}{ccccc}
\hline \multirow{2}{*}{ Class Habitat } & \multicolumn{2}{c}{2009} & \multicolumn{2}{c}{2012} \\
& Prod. Acc. & User Acc. & Prod. Acc. & User Acc. \\
\hline Coral Reef & 67.74 & 65.63 & 55.17 & 57.14 \\
Abiotik & 53.33 & 64.00 & 69.70 & 82.14 \\
Others & 66.67 & 38.10 & 84.21 & 72.73 \\
Vegetation & 72.00 & 80.00 & 86.00 & 81.13 \\
Over all Acc. & & 65.85 & & 74.81 \\
Error & & 34.15 & & 25.19 \\
Kappa Coeff. & & 0.525 & & 0.650 \\
\hline
\end{tabular}

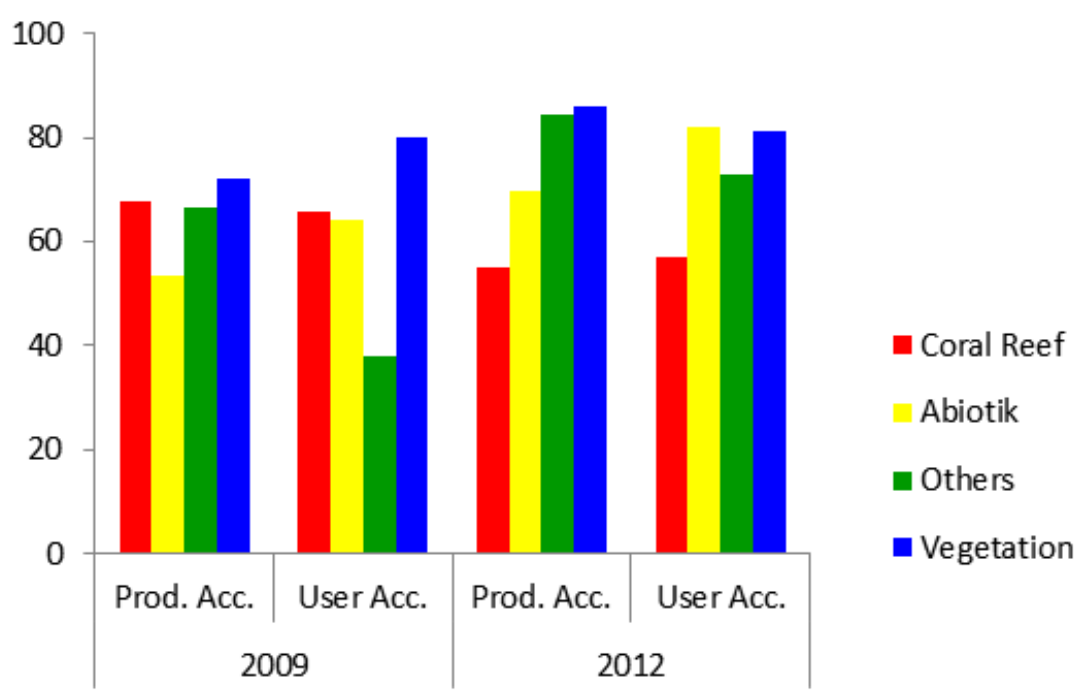

Figure 19. Accuracy test graph

\section{Discussion}

Fill and frame software sucsessful remove a gaps on Landsat 7 ETM+ which will be used in this research. Investigation using 2 landsat image on 2009 and 2 landsat image on 2012, have been remove the gaps without change another pixel are not affect of gaps, except on band 6 and band 8 which has a resolution different from other bands, where the band 6 has a resolution of 60 meters, and band 8 has a resolution of 15 meters, this software has failed to use.

An area after crooping image is about $560,142,000 \mathrm{~m}^{2}$. Unclassified area is about $538,725,600 \mathrm{~m}^{2}(96,18 \%)$ and classification area is about $21,416,400 \mathrm{~m}^{2} \quad(3,82 \%)$. Landsat image 7 ETM+ classification using the maximum likelihood method in ENVI 4.8 obtained coral reefs and others class in 2012 decreased by $18.36 \%$ and $17.29 \%$ from 2009 covered, while the abiotik and vegetation increased $108.77 \%$ and $22.26 \%$ (Table 5).

Abiotic class cover change in 2012 increasing of to $108.77 \%$ percent and vegetation class increasing of to $22.26 \%$, compare class covers at 2009 . This is due to the difference acquisition time of satellite image used in this study. In 2009 the image used is a of Landsat $7 \mathrm{ETM}+$ satellite image on the acquisition of October 15, 2009 (summer), where the seaweed farmers are generally active so that the spectral radiance received by satellite sensor derived from radiance (reflectance) from seaweed cultivation areas. In 2012, using of Landsat 7 ETM+ satellite images on the acquisition of February 26, 2012 (rainy season) where the seaweed farmers are less active in farming so that the spectral radiance received by sensor satellite derived from radiance (reflectance) from bottom waters are generally in the form of sand or rubble. 
Coral class cover decreased $18.36 \%$ and others class cover decreased $17.29 \%$ at the periods 2009-2012. The acquisition of Landsat 7 ETM+ satellite image in 2012 (rainy season) led to the ability of light to penetrated into the water body is limited, because of the athmospheric noisy (clouds, haze, aerosol, etc) and also increasing dissolved sediments in water bodies. It is caused a scattering and an absorption is greater than summer acquisition (2009), so that the spectral radiance (reflectance) at each class on a certain depth be lower even resembling each other. This caused a bias classification in large enough to classified of coral or others class (dominated by soft coral from xeniidae and clavularia $s p$ ), which also perform photosynthesis, then classified into a vegetation class or reverse. Good knowledge of coastal ecosystems and the location of research is very important to understand the classification results.

Reducing the light ability to penetrate into the water body in the rainy season due to increased dissolved sediment, causing the ability of zooxanthallae on coral reefs and soft coral (other class) in conducting photosynthesis capabillity will be reduced, so the spectral radiance received by satellite sensor from the shallow water benthic although became lower, but the spectral range value has a capability to distinguish shallow water benthic types more significantly. This can be seen in the accuracy test on each shallow water benthic class on using Landsat $7 \mathrm{ETM}+$ satellite image of acquired during the rainy season (2012) which showed an accuracy of better than satellite image acquired in the summer (2009) as presented on Table 6. Over all accuracy test results show the value in 2009 amounted to $65.85 \%$ with a kappa coefficient of to 0.525 , while in 2012 obtained an accuracy value of $74.81 \%$ with a kappa coefficient of to 0.650 .

\section{Conclusions and Suggestion}

\subsection{Conclusion}

Trouble SLC (SLC off) on Landsat 7 ETM+ can be improved by using the fill and frame software developed by the USGS, without affecting the pixel values are not have a impact image gaps. Landsat 7 ETM+ is good enough to identify the shallow water benthic in the district of Nusa Penida with accuracy $65.85 \%$ (2009) and $74.81 \%$ (2012), and the kappa coefficient 0.525 (2009) and 0.650 (2012). The accuracy of the classification results of Landsat $7 \mathrm{ETM}+$ image compared to in-situ data classified is in moderate level. This means that the Landsat 7 ETM+ reliable in shallow water benthic mapping with remote sensing technology.

Study area covers was about 560,142,000 m2, consist of two regions, 1) unclassified region (presented to land and depth sea) with an area of 538,725,600 $\mathrm{m} 2$ (96.18\%), and 2) classified region (presented coastal region) with an area of $21,416,400 \mathrm{~m} 2(3.82 \%)$. Change detection in this area from 2009 until 2012 obtained coral reefs classes cover decreased by $18.36 \%(6,121,800 \mathrm{~m} 2$ to $4,997,700 \mathrm{~m} 2)$, abiotic class cover increased by $108.77 \%(2,329,200 \mathrm{~m} 2$ to $4,862,700 \mathrm{~m} 2)$, others classes cover decreased by $17.27 \%$ $(10,512,000 \mathrm{~m} 2$ to $8,694,900 \mathrm{~m} 2)$ and vegetation classes cover increased by $22.27 \%$ $(2,453,400 \mathrm{~m} 2$ to $2,999,700 \mathrm{~m} 2)$. With a classified area about $21,416,400 \mathrm{~m} 2$ (ignored unclassified area), live coral cover area of $28.59 \%$ in 2009 and decreased to $23.34 \%$ in 2012. The condition of live coral cover at Nusa Penida district decreased from moderate (2009) to damage (2012).

Live coral is found in nearly all Nusa Penida coastal area with the highest concentrations found in the western and southern part of Nusa Lembongan. Abiotic class is uniformly dispersed in high concentrations at western and sothern part of Nusa Lembongan. Others class is a dominant class in 2009, with cover evenly across the coast of Nusa Penida. But in 2012, the concentration decreased and spread in large concentrations in the south and east of the Nusa Penida island. Vegetation classes are generally concentrated in the northern, southern and eastern part of the Nusa Lembongan.

\subsection{Suggestion}

Ideally, when we want to compare between satellite image data compare with in-situ data in the depth water with Point Intercept Transeck (PIT) or a similar method such as Line 
Intercept Transeck (LIT) method, we can choose to use a high-resolution satellite image with a precision equal or close to the interval between the points on the line transect

Using a hight resolution satellite image with a good geometric correction and good athmospheric correction, will give a best accuracy, because 1 pixel on satellite image can be represented by 1-2 point of the benthic sample at in-situ data. With high resolution satellite image, we can identified more of benthic class in the shallow water benthic.

\section{References}

Allen, G. R., \& Werner, T. B. (2002). Coral reef fish assessment in the 'coral triangle'of southeastern Asia. Environmental Biology of Fishes, 65(2), 209-214.

Armstrong, R. A. (1993). Remote sensing of submerged vegetation canopies for biomass estimation. International Journal of Remote Sensing, 14(3), 621-627.

Bukata, R. P., Jerome, J. H., Kondratyev, A. S., \& Pozdnyakov, D. V. (2018). Optical properties and remote sensing of inland and coastal waters. Boca Raton, USA: CRC press.

Campbell, J. B., \& Wynne, R. H. (2011). Introduction to remote sensing. New York, USA: Guilford Press.

Chander, G., Markham, B. L., \& Helder, D. L. (2009). Summary of current radiometric calibration coefficients for Landsat MSS, TM, ETM+, and EO-1 ALI sensors. Remote sensing of environment, 113(5), 893-903.

Darma, N., Basuki, R., \& Welly, M. (2010). Profil Kawasan Konservasi Perairan (KKP) Nusa Penida, Kabupaten Klungkung, Propinsi Bali. Denpasar, Indonesia: Pemerintah Daerah Kabupaten Klungkung.

English, S. S., Wilkinson, C. C., \& Baker, V. V. (1997). Survey manual for tropical marine resources. Townsville, Australia: Australian Institute of Marine Science.

Giyanto, A. M., Hadi, T. A., Budiyanto, A., Hafizt, M., Salatalohy, A., \& Iswari, M. Y. (2017). Status Terumbu Karang Indonesia 2017. Pusat Oseanografi-LIPI, Jakarta.

Green, E., Mumby, P., Edwards, A., \& Clark, C. (2000). Remote Sensing: Handbook for Tropical Coastal Management. Paris, France: United Nations Educational, Scientific and Cultural Organization (UNESCO).

Gomez, E. D., \& Yap, H. T. (1998). Monitoring Reef Condition. Page: 187-195 in RA Kenchington dan $B E T$ Hudson. Jakarta, Indonesia: UNESCO Regional Office for Science and Technology for South East Asia.

Hoegh-Guldberg, O., Hoegh-Guldberg, H., Veron, J.E.N., Green, A., Gomez, E. D., Lough, J., King, M., Ambariyanto, Hansen, L., Cinner, J., Dews, G., Russ, G., Schuttenberg, H. Z., Peñaflor, E.L., Eakin, C. M., Christensen, T. R. L., Abbey, M., Areki, F., Kosaka, R. A., Tewfik, A., Oliver, J. (2009). The Coral Triangle and Climate Change: Ecosystems, People and Societies at Risk. WWF Australia, Brisbane, $276 \mathrm{pp}$.

Kirkman, H., Oliver, L., \& Digby, B. (1988). Mapping of underwater seagrass meadows. In Proceedings of an International Symposium on Remote Sensing of the Coastal Zone. Gold Coast, Australia, 7-9 September 1988 (pp. 2, 1-2, 9)

Lillesand, T., Kiefer, R. W., \& Chipman, J. (2004). Remote sensing and image interpretation. (5th ed). New York, USA: John Wiley \& Sons.

LIPI. (2012). delivered by S.C Sutardjo, Minister of Marine Fisheries of the Republic of Indonesia in the International Coral Reef Symposium - Jakarta on 4 July 2013, available on URL http://www.coremap.or.id/berita/article.php?id=1135 (visited on 5 September 2013 at 21.40 WITA).

Lyzenga, D. R. (1981). Remote sensing of bottom reflectance and water attenuation parameters in shallow water using aircraft and Landsat data. International journal of remote sensing, 2(1), 7182.

Maingi, J. K., Marsh, S. E., Kepner, W. G., \& Edmonds, C. M. (2002). An Accuracy Assessment of 1992 Landsat-MSS Derived Land Cover for the Upper San Pedro Watershed(US/Mexico). Report. Washington, D.C., USA: United States Environmental Protection Agency.

Muljadi, A. H., \& Welly, M. (2012). Protokol biofisik monitoring kesehatan karang Kawasan Konservasi Perairan Nusa Penida. Report. Denpasar, Indonesia: Coral Triangle Center.

NASA. (2014). available on URL : http://geo.arc.nasa.gov/sge/landsat/17.html, (visited on 30 January, 2014, at 21.00 WITA).

Scaramuzza, P., Micijevic, E., \& Chander, G. (2004). SLC gap-filled products phase one methodology. Landsat Technical Notes No. 5. 
Scaramuzza, P., \& Barsi, J. (2005). Landsat 7 scan line corrector-off gap-filled product development. In Proceeding of the Pecora 16 "Global Priorities in Land Remote Sensing". Sioux Falls, South Dakota, 23-27 October 2005 (pp. 23-27).

USGS. (2004). SLC-OFF Gapfill Product : Gapfill Alghoritm Metodology. http://landsat.usgs.gov/documents/L7SLCGapfilledMethod.pdf. (visited on 31 May 2014, at 12.15 WITA).

Veron, J. E. N., Devantier, L. M., Turak, E., Green, A. L., Kininmonth, S., Stafford-Smith, M., \& Peterson, N. (2009). Delineating the coral triangle. Galaxea, Journal of Coral Reef Studies, 11(2), 91-100.

(C) 2018 by the authors; licensee Udayana University, Indonesia. This article is an open access article distributed under the terms and conditions of the Creative Commons Attribution (CC-BY) license (http://creativecommons.org/licenses/by/4.0/). 